\title{
Calcium Entry Mechanisms in Salivary Glands
}

\author{
James W Putney Jr.
}

National Institute of Environmental Health Sciences-NIH, Department of Health and Human Services, 111 TW Alexander Drive, PO Box 12233, Research Triangle Park, NC 27709, USA

Correspondence to :

James W Putney Jr.

E-mail: putney@niehs.nih.gov

Keywords :

salivary glands, signal transduction, calcium signaling, calcium entry, calcium channels

\begin{abstract}
The organic and inorganic milieu of the oral cavity is regulated in large part through the secretions of salivary glands. These secretions are activated by a number of cellular signaling mechanisms, a major one being the cellular $\mathrm{Ca}^{2+}$ signaling system. Activation of phospholipase $\mathrm{C}$ by $\mathrm{G}$-protein-coupled receptors results in release of intracellular $\mathrm{Ca}^{2+}$ and activation of $\mathrm{Ca}^{2+}$ channels in the plasma membrane. The intracellular release of $\mathrm{Ca}^{2+}$ is signaled by the second messenger, inositol 1,4,5-trisphosphate. $\mathrm{Ca}^{2+}$ entry involves signaling from depleted intracellular stores to plasma membrane $\mathrm{Ca}^{2+}$ channels, a process referred to as capacitative calcium entry or store-operated calcium entry. The electrophysiological current associated with capacitative calcium entry is the calcium-release-activated calcium current, or $I_{\text {crac }}$. In the twenty years since the inception of the concept of capacitative calcium entry, a variety of activation mechanisms have been proposed, and there has been considerable interest in the possibility of transient receptor potential channels functioning as store-operated channels. However, in the past two years, two major players in both the signaling and permeation mechanisms for store-operated channels have been discovered: Stim1 (and possibly Stim2) and the Orai proteins. Activation of store-operated channels involves an endoplasmic reticulum $\mathrm{Ca}^{2+}$ sensor called Stim1. Stim1 acts by redistributing within a small component of the endoplasmic reticulum, approaching the plasma membrane, but does not appear to translocate into the plasma membrane. Stim1, either directly or indirectly, signals to plasma membrane Orai proteins which constitute pore-forming subunits of store-operated channels.
\end{abstract}

\section{Introduction}

The normal physiological milieu of the oral cavity is influenced by a number of environmental factors, both internal and external. Among the most important internal factors is the amount and composition of saliva. Saliva is well documented to be important for maintaining oral health, and especially dental health (1-5). Thus, understanding abnormalities in salivary gland function, for example in Sjogren's syndrome (3), is key to efforts to circumvent these abnormalities and restore normal salivary function.

The process of salivation is a complex one. While there is a certain constant, constitutive flow of secretion into the oral cavity, the majority of saliva is generated in response to complex reflex neural mechanisms that greatly increase the rate of salivary flow. These neural mechanisms culminate in the release of neurotransmitters primarily onto salivary acinar cells. Activation of the neurotransmitter receptors on the acinar cell surface activates basic signaling mechanisms which set into play complex cellular responses that culminate in the generation of transepithelial fluid flow, and the exocytotic discharge of macromolecules $(6,7)$.

Two basic signaling pathways regulate salivary secretion. Both involve the activation of surface membrane receptors linked to guanine nucleotide dependent transducers, or G-proteins. The G-pro- 
teins activate effector enzymes that produce specific second messenger molecules. One, linked primarily to $\beta$-adrenergic receptors activated by sympathetic input, acts through the second messenger cyclic AMP. Cyclic AMP activates a specific kinase leading to phosphorylation of proteins that regulate both exocytotic secretion and fluid secretion $(6,8-11)$. The second major pathway involves activation of phospholipase $\mathrm{C}$ and generation of second messengers, inositol 1,4,5-trisphosphate $\left(\mathrm{IP}_{3}\right)$ and diacylglycerol (DAG) (12).

\section{Activation of phospholipase C}

Salivary glands contain a number of different $\mathrm{G}^{-}$ protein coupled receptors that link to the activation of phospholipase $\mathrm{C}$, including cholinergic muscarinic, alpha- 1 adrenergic, substance $\mathrm{P}$, and $\mathrm{P} 2 \mathrm{Y}$ purinergic, to name a few. These receptors act through G-proteins of the $G_{q / 11}$ class to activate phospholipase $C$ (PLC), primarily PLC $\beta$. PLC cleaves plasma membrane phosphatidylinositol 4,5-bisphosphate $\left(\mathrm{PIP}_{2}\right)$ to produce the $\mathrm{Ca}^{2+}$-signaling messenger, $\mathrm{IP}_{3}$, and the protein kinase $\mathrm{C}$-activating messenger, DAG (13). These two pathways interact in the regulation of protein secretion which appears to operate optimally with a combined $\mathrm{Ca}^{2+}$ and protein kinase $\mathrm{C}$ signal (14). $\mathrm{Ca}^{2+}$ also serves as a signal for regulating membrane ion channels leading to fluid secretion; the role of protein kinase $\mathrm{C}$ in this pathway is less clear.

\section{Two phases of $\mathrm{Ca}^{2+}$ signaling}

Activation of PLC in salivary gland cells results in production of $\mathrm{IP}_{3}$ and a subsequent rise in the concentration of $\mathrm{Ca}^{2+}$ in the cytoplasm, generally referred to as a $\mathrm{Ca}^{2+}$ signal. In the initial studies of $\mathrm{Ca}^{2+}$ signaling in salivary gland preparations in vitro, indirect measures of cytoplasmic $\mathrm{Ca}^{2+}$ were employed, for example, the activity of $\mathrm{Ca}^{2+}$-activated $\mathrm{K}^{+}$channels by measuring the rate of ${ }^{86} \mathrm{Rb}^{+}$efflux (Fig. 1). From these earliest measurements, it soon became obvious that the $\mathrm{Ca}^{2+}$ signal was comprised of two distinct phases: an initial phase that was independent of extracellular $\mathrm{Ca}^{2+}$ and involved release of $\mathrm{Ca}^{2+}$ from the cell's interior, and a second, more sustained phase that involved the activation of $\mathrm{Ca}^{2+}$ entry into the cell across the plasma membrane $(15,16)$ (Fig. 1). The mechanism underlying the first, $\mathrm{Ca}^{2+}$-release phase, is attributed to the action of the PLC product, $\mathrm{IP}_{3}(13,17) . \mathrm{IP}_{3}$ releases $\mathrm{Ca}^{2+}$ from the endoplasmic reticulum, or a specialized component of it, by binding to and activating specific $\mathrm{IP}_{3}$ receptor/ion channels in the endoplasmic reticulum membrane (18). Early studies indicated that the pools of $\mathrm{Ca}^{2+}$ regulated by different $\mathrm{PLC}-$ coupled receptors were coincident, as expected if regulated by a common diffusible messenger (16). With lower, more physiological concentrations of agonists, this release often occurs in the form of repetitive transient rises referred to as $\mathrm{Ca}^{2+}$ oscillations $(19,20)$. Oscillations can take either of two forms: baseline spikes or sinusoidal oscillations (21). In the parotid gland, the predominant form is sinusoidal $(22,23)$. These oscillations likely result from fluctuations in PLC activity due to negative feedback from protein kinase C (23).

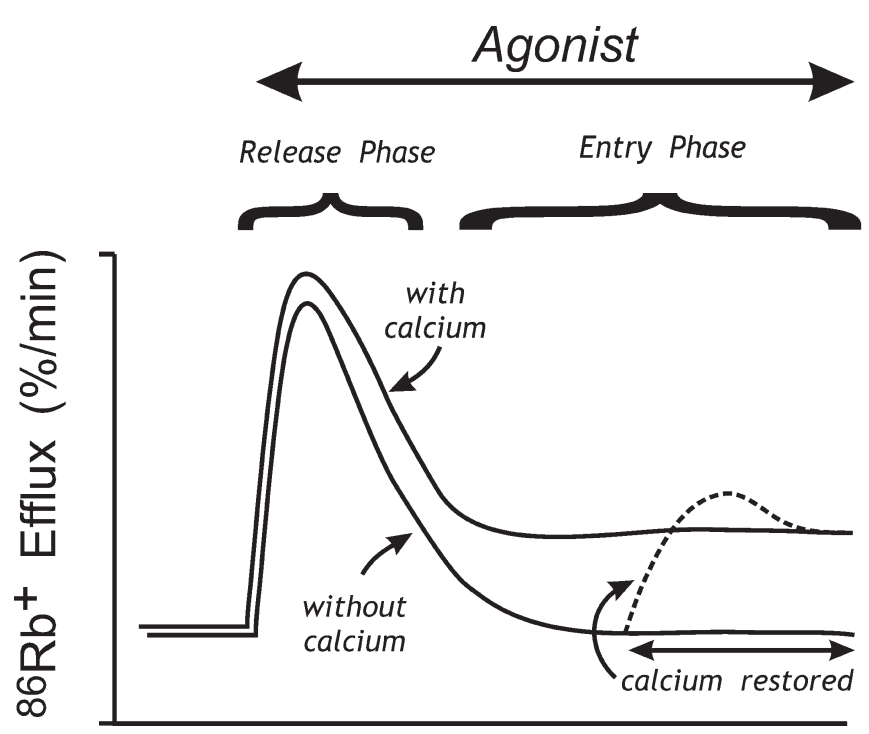

\section{Time}

Fig. 1. Pattern of $\mathrm{Ca}^{2+}$ signaling in parotid cells revealed by flux of ${ }^{86} \mathrm{Rb}^{+}$. The rate of efflux of ${ }^{86} \mathrm{Rb}^{+}$is monitored as an index of the activity of $\mathrm{Ca}^{2+}$-activated $\mathrm{K}^{+}$channels. Addition of an agonist for a phospholipase $\mathrm{C}-$ coupled receptor leads to an increase in $\left[\mathrm{Ca}^{2+}\right]_{\mathrm{i}}\left({ }^{86} \mathrm{Rb}^{+}\right.$flux $)$which is sustained in the presence, but transient in the absence of external $\mathrm{Ca}^{2+}$. These two phases represent $\mathrm{Ca}^{2+}$ signaling due to release (initial transient) and $\mathrm{Ca}^{2+}$ entry across the plasma membrane (sustained component). 
Accompanying or immediately following the $\mathrm{Ca}^{2+}$ release phase of the response is a phase of $\mathrm{Ca}^{2+}$ signaling involving $\mathrm{Ca}^{2+}$ entry into the cell through channels in the plasma membrane (16). Consistent with the idea of a common pool of $\mathrm{Ca}^{2+}$ controlled by different PLC-coupled receptors, it was also apparent that a single population of $\mathrm{Ca}^{2+}$ channels were regulated by different receptor types (16). While the molecular basis for the intracellular release of $\mathrm{Ca}^{2+}$ was quickly solved ( $\mathrm{IP}_{3}$ and $\mathrm{IP}_{3}$ receptors), the molecular basis for the coupled activation of $\mathrm{Ca}^{2+}$ entry into salivary gland cells, and other cells in which PLC played a predominant role was not understood until very recently. This story will be the main focus of the remainder of this review.

\section{Capacitative Calcium Entry}

Experiments carried out in parotid gland cells provided the first evidence for a mechanism called capacitative calcium entry or store-operated calcium entry (16, 24-26). The term "capacitative" calcium entry was originally meant to imply this continuous loading and discharge of a $\mathrm{Ca}^{2+}$ store, much as in an electrical circuit, charge must load a capacitator before current can flow through it. In my own mind, this obligatory linkage of release to entry came about from experiments showing reloading of stores through $\mathrm{Ca}^{2+}$ entry in parotid and lacrimal acinar cells in two studies published in 1977 (16) and 1978 (27), the latter being the first report to demonstrate refilling of $\mathrm{Ca}^{2+}$ stores independently of receptor activation. These two papers concluded that the process of $\mathrm{Ca}^{2+}$ entry and release were essentially one and the same, and that entry proceeded through release sites to the cytoplasm. It was not clear where the release sites were at that time, and for the sake of simplicity, it was assumed the $\mathrm{Ca}^{2+}$ was bound to the plasma membrane itself (Fig. 2).

The precise pathway by which $\mathrm{Ca}^{2+}$ reloaded the internal stores was not initially clear; in 1978 I pointed out that no activation of $\mathrm{K}^{+}\left({ }^{86} \mathrm{Rb}^{+}\right)$efflux (an indicator of $\left[\mathrm{Ca}^{2+}\right]_{\mathrm{i}}$ changes) was observed $(24,27)$, suggesting either a direct route, or possibly one compartmentalized or protected from the bulk of

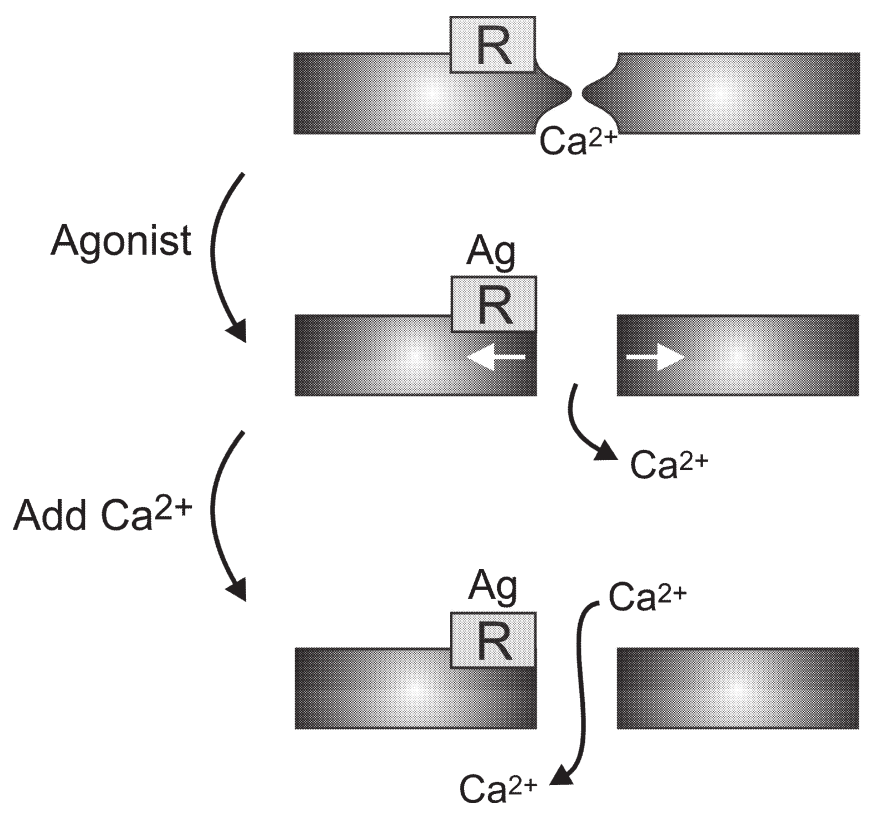

Fig. 2. Primitive version of capacitative calcium entry. The intracellular $\mathrm{Ca}^{2+}$ store was envisioned as bound to the plasma membrane, occluding the $\mathrm{Ca}^{2+}$ channel. release of the bound $\mathrm{Ca}^{2+}$ was associated with gating of the $\mathrm{Ca}^{2+}$ channel. The figure is similar to one first presented in (16).

cytoplasm. This of course turned out to be wrong. With hindsight, it is now clear that the failure of $\left[\mathrm{Ca}^{2+}\right]_{\mathrm{i}}$ to rise significantly during refilling is simply due to the buffering speed of endoplasmic reticulum matching or exceeding the rate of $\mathrm{Ca}^{2+}$ entry, and possibly (see below) close apposition of plasma membrane channels with endoplasmic reticulum uptake sites. In fact, in some cell types, when the rate of re-filling is pushed to the maximum, transient elevation of $\left[\mathrm{Ca}^{2+}\right]_{\mathrm{i}}$ is observed (25). However, the clearest evidence that $\mathrm{Ca}^{2+}$ must enter the cytoplasm directly came from experiments with the sarcoplasmic-endoplasmic reticulum $\mathrm{Ca}^{2+}$ ATPase inhibitor, thapsigargin (26), and from the subsequent demonstration of a store-operated $\mathrm{Ca}^{2+}$ current by Hoth and Penner (28).

\section{Action of Thapsigargin}

Experiments with the sarcoplasmic-endoplasmic reticulum $\mathrm{Ca}^{2+}$ ATPase (SERCA) inhibitor, thapsigargin, in parotid cells provided an important proof for the concept of capacitative calcium entry. The ability to activate $\mathrm{Ca}^{2+}$ entry simply by blocking the intracellular pumps responsible for its sequestration 
led to a number of important conclusions (26). First, it was possible to show that entry could be fully activated with no discernible activation of phospholipase C. Second, additivity experiments showed that, at least in the parotid cells that were initially studied, there was no additional pathway activated through phospholipase $\mathrm{C}$-linked muscarinic receptors. Third, the fact that thapsigargin activated $\mathrm{Ca}^{2+}$ entry to the same extent as phospholipase C activation, but without increasing $\mathrm{IP}_{3}$ demonstrated that passage through the endoplasmic reticulum was not required for access to the cytoplasm; i.e., the permeability of the endoplasmic reticulum membrane to $\mathrm{Ca}^{2+}$ was not a determinant of the rate at which $\mathrm{Ca}^{2+}$ entered the cytoplasm. This and other arguments favoring a transmembrane flux of $\mathrm{Ca}^{2+}$ rather than a transit through intracellular stores were summarized in an earlier review (29).

But, perhaps the most significant outcome of the discovery of thapsigargin and other SERCA-inhibiting drugs (Fig. 3) was that it provided a precise functional and pharmacological definition of

\section{SERCA Inhibitors}

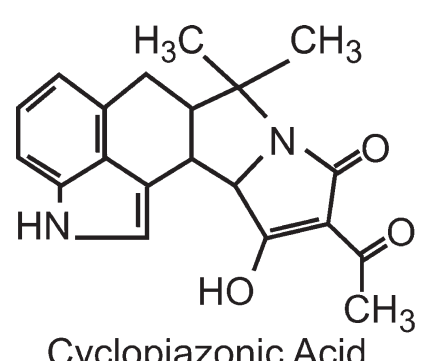

Cyclopiazonic Acid

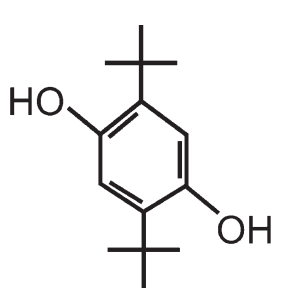

2,5-di-[tert-butyl]-1,4benzohydroquinone (DBHQ)

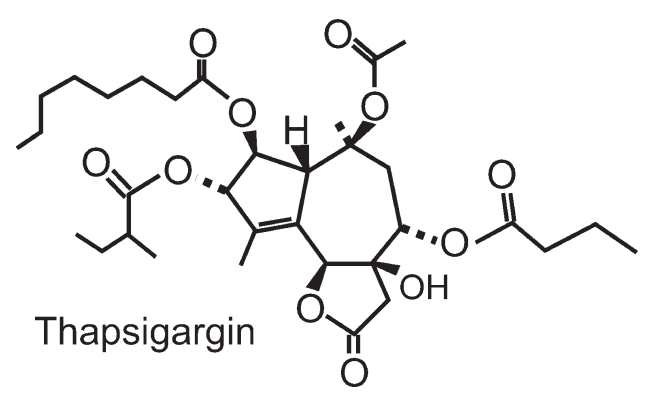

Fig. 3. Structures of commonly employed inhibitors of sarcoplasmic-endoplasmic reticulum $\mathrm{Ca}^{2+}$ ATPase (SERCA). capacitative entry. Notably, the ability of thapsigargin to specifically activate capacitative calcium entry, while minimizing the roles of other upstream players in the pathway (receptors, G-proteins, phospholipase $\mathrm{C}$, etc.) formed the basis for the high throughput assays that led to the discoveries of two significant molecular players in this pathway, discussed in a later section, Stim and Orai.

\section{$I_{\text {crac }}$}

That $\mathrm{Ca}^{2+}$ entered the cytoplasm by directly traversing the plasma membrane was unequivocally established by the demonstration of a store-operated or capacitative calcium entry transmembrane current (28). Hoth and Penner $(28,30)$ named this current $C$ alcium-Release-Activated $\mathrm{Ca}^{2+}$ current, or $I_{\text {crac }}$, and provided a thorough biophysical characterization of this very small but highly $\mathrm{Ca}^{2+}$-selective current. $I_{\text {crac }}$ shared some properties with previously studied $\mathrm{Ca}^{2+}$-selective voltage-activated currents. For example, $I_{\text {crac }}$ demonstrated an anomalous mole fraction effect ; removing external $\mathrm{Ca}^{2+}$ led to loss of current, unless all external divalent cations were removed with chelators, in which case the currents became permeable to monovalent cations, and were actually larger than when conducting $\mathrm{Ca}^{2+}$. However, $I_{\text {crac }}$ differed from other known currents in one significant way : the single channel conductance was too small to be measured directly, and was subsequently estimated indirectly by noise analysis by Zweifach and Lewis (31) to be of the order of $24 \mathrm{fS}$ (in isotonic $\mathrm{Ca}^{2+}$ ). This finding suggests that the molecular structure of CRAC channels and the other known $\mathrm{Ca}^{2+}$ channels might be very different (which in fact has turned out to be the case). In addition, $I_{\text {crac }}$ showed unusual regulation by $\mathrm{Ca}^{2+}$; intracellular $\mathrm{Ca}^{2+}$ inhibited the channels by multiple mechanisms $(30,32)$, while extracellular $\mathrm{Ca}^{2+}$ potentiated channel function (33). These and a number of other findings provided a rigorous fingerprint for the CRAC channel that eventually aided in its correct molecular identification. 


\section{Numerous activation mechanisms are proposed}

Several reviews have summarized the ideas that have come in and out of vogue in the last twenty years regarding the activation mechanism for capacitative calcium entry (34-40). Three fundamental mechanisms have been proposed for transmitting the signal from intracellular stores to the plasma membrane: (i) a diffusible message, (ii) conformational coupling (35), and (iii) vesicle secretion (41).

The idea of a diffusible message for capacitative calcium entry was proposed when it was realized that no special path for calcium entry through the endoplasmic reticulum existed, and that the calcium entered the cell directly across the plasma membrane into the cytoplasm (29). Subsequently, a considerable number of publications have argued for a diffusible signal coupling depletion of intracellular $\mathrm{Ca}^{2+}$ stores to calcium entry, and some evidence, albeit more controversial, for the involvement of specific mediators. Some have suggested involvement of cyclic GMP (42, 43, 43), others, arachidonic acid (or one of its metabolites) (44-46) ; however, it now seems likely that these mediators act on channels distinct from the store-operated ones $(47,48)$. The one candidate for a diffusible signal for store-operated channels that has withstood the test of time is one whose structure is as yet not known: a $\mathrm{Ca}^{2+}$ entry-activating principle partially isolated from store-depleted cells called CIF (for Calcium Influx Factor) (39, 49, 50). The first experimental evidence for such a messenger was provided by Randriamampita and Tsien (49). They described an activity in extracts of stimulated Jurkat $\mathrm{T}$ cells that increased $\mathrm{Ca}^{2+}$ entry in several cell types. This activity they termed "CIF" for Calcium Influx Factor. Further fractionation and purification of cell extracts produced an activity, probably different from the first CIF described by Randriamampita and Tsien, that potently activated $\mathrm{Ca}^{2+}$ influx when injected into Xenopus oocytes (51) or when applied to patches containing excised, store -operated channels $(52,52,53,53,54)$. The most recently published data on CIF action present a compelling case for such a molecule, and suggest a mechanism whereby $\mathrm{CIF}$ acts to regulate a $\mathrm{Ca}^{2+-}$ independent phospholipase $A_{2}$ which in turn generates a channel-activating lysophospholipid (53-56). The role, if any, of CIF in the newly discovered Stim1 -dependent activation mechanism, discussed below, awaits additional experimental work.

(54) Irvine (57) (see also (35)) proposed a conformational coupling model based on the known interaction between plasma membrane dihydropyridine receptors (voltage-dependent calcium channels) and intracellular ryanodine calcium release channels in skeletal muscle. In the phospholipase $\mathrm{C}$ signaling system, endoplasmic reticulum $\mathrm{IP}_{3}$ receptors were proposed to interact directly with plasma membrane capacitative calcium entry channels. In the case of skeletal muscle, information flows from the t-tubule membrane to the sarcoplasmic reticulum; in the case of the $\mathrm{IP}_{3}$ receptor and capacitative calcium entry, a fall in luminal $\mathrm{Ca}^{2+}$ in the endoplasmic reticulum would induce a conformational change in the $\mathrm{IP}_{3}$ receptor, and this would be conveyed directly to the plasma membrane channel via a protein-protein interaction. This was an intriguing idea, but there was little direct evidence for it. There is however, evidence for a requirement for close spatial association between endoplasmic reticulum and plasma membrane store-operated channels. Jaconi et al. (58) utilized centrifugation to redistribute the organellar contents of oocytes and found that entry only occurred in regions with closely apposed endoplasmic reticulum. Patterson et al. (59) used drugs to stimulate peripheral actin polymerization, and disrupted communication between $\mathrm{Ca}^{2+}$ stores and plasma membrane store-operated channels (but see (60)).

\section{TRP channels}

Hardie and Minke $(61,62)$ first realized that the Drosophila photoreceptor calcium channel, TRP, was activated downstream of phospholipase $\mathrm{C}$ and might be a candidate for a store-operated channel. When mammalian homologs were cloned ((63) the canonical TRPs, or TRPCs), a number of laboratories pursued this possibility, with initially encouraging results (63-65). However, it soon became apparent 
that many of the early findings likely resulted from constitutive activity of over-expressed channels (66, 67). Nonetheless, there are numerous reports of diminished store-operated entry following knockdown of TRPC expression (for example, (68), and others reviewed in (40)). Also, it is clear that under some circumstances, TRPC channels can exhibit store-operated activity when ectopically expressed (69-72).

An important issue is that TRPC channels, when experimentally expressed, do not recapitulate the properties of $I_{\text {crac }}$; rather, they form non-selective cation channels, or at best channels with only modest $\mathrm{Ca}^{2+}$ selectivity. Additionally, they have single channel conductances of conventional size, on the order of tens of picosiemens. Thus, if TRPC channels operated as store-operated channels, it would appear that these channels should have characteristics clearly distinct from $I_{\text {crac }}$ (for example, (54), others reviewed in (40)). On the other hand, there is a clear and generally reproducible body evidence showing that TRPC channels can be activated downstream of PLC by mechanisms not involving store depletion, for example, TRPC3, 6 and 7 by diacylglycerols, and there is ample evidence that such a mode of regulation occurs in cells under conditions of physiological regulation (73-77).

\section{The role of Stim1}

The role of Stim1 (actually, initially Drosophila Stim) in capacitative calcium entry was initially discovered through a limited RNAi screen of thapsigargin-activated $\mathrm{Ca}^{2+}$ entry in Drosophila S2 cells by Roos et al. (78). This was followed shortly thereafter by a report from Liou et al. (79) who carried out a limited RNAi screen using thapsigargin-activated mammalian HeLa cells. Drosophila has a single Stim gene, while mammalian cells have two, designated Stim1 and 2. In the Roos et al. study, following the identification of Stim from the S2 screen, they found that knockdown of Stim1, but not Stim2 reduced store-operated entry and $I_{\text {crac }}$ in mammalian cells. However, Liou et al. reported a slight reduction in $\mathrm{Ca}^{2+}$ entry by knockdown of Stim2 in HeLa cells.
Soboloff et al. (80) reported that Stim2 could act as an inhibitor of store-operated entry; however, this action of Stim2 was only seen when expressed at very high levels. Thus the true physiological function of Stim2 may not yet be known.

It seems clear that the function of Stim1 is to act as the initial sensor of $\mathrm{Ca}^{2+}$ levels in the endoplasmic reticulum, or the component of it involved in regulation of $I_{\text {crac }}$. The $\mathrm{Ca}^{2+}$ sensing domain is an EF-hand that resides in the lumen of the endoplasmic reticulum, $\mathrm{N}$-terminal to the single transmembrane segment. Several laboratories have demonstrated that mutations in the $\mathrm{EF}$-hand region, presumably reducing $\mathrm{Ca}^{2+}$ affinity, result in constitutive activation of $\mathrm{Ca}^{2+}$ entry with properties expected of $I_{\text {crac }}$ (79, 81-83).

Experiments examining the cellular distribution of Stim1 histochemically, or utilizing expression of fluorescent protein fusion constructs have provided intriguing information on the cell biology of this $\mathrm{Ca}^{2+}$ sensor. An important finding is that the intracellular distribution of Stim1 does not match well with markers for endoplasmic reticulum. Labeled (YFP) Stim1 appears as fibrillar, or more likely tubular structures in HEK293 cells (Fig. 4) (83), structures not apparent from labeling generic endoplasmic reticulum in the same cell type (84). It is likely that Stim1 will serve to define a distinct organelle, or more likely a distinct compartment within the endoplasmic reticulum. This is gratifyingly consistent with a number of previous studies which concluded
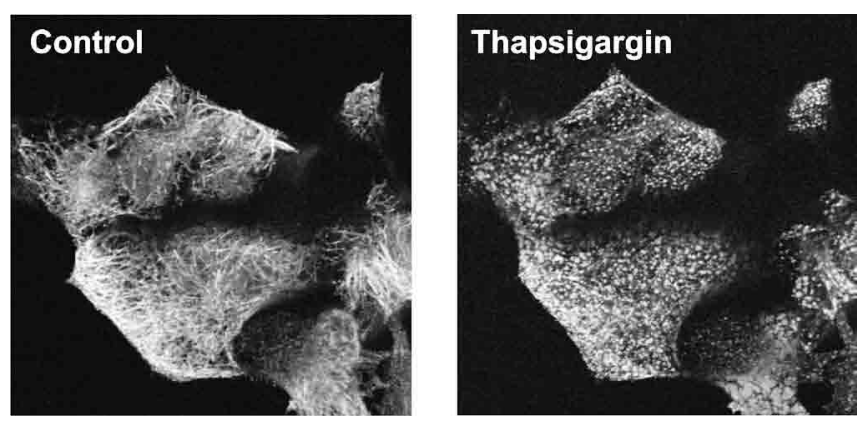

Fig. 4. Stim1 rearranges following $\mathrm{Ca}^{2+}$ store depletion. Confocal images demonstrating that thapsigargin causes rearrangement of YFP-Stim1 from a fibrillar or tubular arrangement into punctae. 
that the pool of $\mathrm{Ca}^{2+}$ that regulated store-operated channels appears to be a small component of the total endoplasmic reticulum (85-90).

As interesting as the subcellular localization of Stim1 may be, what is more exciting is the idea that $\mathrm{Ca}^{2+}$ dissociation causes the protein to redistribute intracellularly. Liou et al. (79) first showed that upon $\mathrm{Ca}^{2+}$ store depletion Stim1 appeared to redistribute into punctate structures, and move closer to the plasma membrane. This has been confirmed in a number of laboratories (81-83) (Fig. 4). However, a major point of controversy remains regarding the localization of Stim1 when it redistributes into punctae. Liou et al. reported that Stim1 moved close to the plasma membrane, but using an antibody directed against the YFP on the $\mathrm{N}$-terminus, they failed to detect Stim1 on the plasma membrane (79). Similar findings were reported by Mercer et al. (83) and by Baba et al. (91). These latter authors found that $\mathrm{N}^{-}$ terminally Flag-tagged Stim1 could not be detected in the plasma membrane of a B-cell line, but still was capable of supporting full store-operated entry. In this case, complete knockout of Stim1 was achieved by targeted gene disruption, leaving no doubt that the N-terminally tagged Stim1 could function in the absence of any residual wild-type protein. And, as will be discussed subsequently, it is possible to greatly increase store-operated entry by $\mathrm{co}^{-}$expression of Stim1 with Orai1; however, even these very large $I_{\text {crac }}$-like currents were supported by YFP-Stim1, again with no surface expression detected (83). On the other hand, based on surface biotinylation studies, Zhang et al. (81) reported that Stim1 actually translocates into the plasma membrane. A third position was taken by Spassova et al. (82) who reported that a fraction of Stim1 was clearly present in the plasma membrane where it appears to function in store-operated entry (based on the inhibition of entry by extracellular application of an anti-Stim1 antibody), but they failed to see any change in the amount of plasma membrane Stim1 following $\mathrm{Ca}^{2+}$ store depletion.

The first report on Stim1, prior to its disclosure as an initiator of capacitative calcium entry, identified it as a surface protein of stromal cells able to interact with B lymphocytes (92), and this surface localization was substantiated in subsequent studies (93, 94). One interpretation of these disparate findings is that native Stim1 is located in the endoplasmic reticulum and in the plasma membrane, but the addition of YFP or a Flag tag to the N-terminus of Stim1 prevents its trafficking to the plasma membrane. This is actually fortuitous, since it allows assessment of the function of Stim1 with a construct restricted to intracellular sites. Thus, one reasonable conclusion is that Stim1 does not translocate to the plasma membrane in response to $\mathrm{Ca}^{2+}$ store depletion. And plasma membrane Stim1, although likely present, does not play an obligatory role in activating store-operated channels.

\section{The role of Orais}

Orai1 was originally discovered by Feske et al. (95) from a combination of gene mapping of a family with an immunodeficiency attributed to loss of $I_{\text {crac }}$ and a whole-genome screen of Drosophila S2 cells. Orail is located in the plasma membrane and appears to have four transmembrane domains. However, unlike the case for Stim1, which was included in restricted screens based on its signaling domains, Orai1 has no recognizable signaling or channel-like domains and thus required the full genome screen. Very soon thereafter, two other groups, also using a similar whole-genome screens of S2 cells, reported on the requirement for Orai (termed CRACM1 by Vig et al. (96)) for store-operated entry and for $I_{\text {crac }}(96$, 97). Zhang et al. (97) also reported that when Drosophila Orai and Stim were co-expressed they appeared to synergize to form unusually large $I_{\text {crac }}$-like currents. This synergy was subsequently confirmed for mammalian Stim1 and Orail by other laboratories $(83,98,99)$. I $I_{\text {crac }}$ current densities were increased up to 50 fold by the combination of Stim1 and Orail, and the resulting currents were indistinguishable from native $I_{\text {crac }}$ in both biophysical and pharmacological properties $(83,98,99)$. This result indicates that these two proteins can fully recapitulate the properties of $I_{\text {crac }}$, a finding notably missing 
in all previous studies of TRP channels; in fact, it is the distinctly different pharmacology or selectivity of TRP channels that revealed that TRP channels could function in a store-operated mode in some instances $(69-71,100)$. This does not necessarily mean that no other players are involved; however, other proteins functioning in a stoichiometric complex with Stim1 and/or Orail would have to be constitutively present in considerable excess.

The large $I_{\text {crac }}$-like currents observed with expression of Stim1 and Orai1 immediately led to speculation that Orai1 was likely the CRAC channel itself, or possibly a subunit of it. However, there are no obvious channel pore-like sequences in Orai1. Three laboratories focused on a string of acidic residues near the extracellular boundary of the first transmembrane domain (101-103). The most interesting mutations targeted a glutamate in position 106 in mammalian Orail (or the corresponding residue in Drosophila Orai). Mutation to alanine resulted in a non-functional channel; however, the conservative mutation of this glutamate to an aspartate (E106D ; E180D in Drosophila Stim) resulted in a channel with markedly reduced selectivity for $\mathrm{Ca}^{2+}$. This provides strong evidence that this residue functions as part of the $\mathrm{Ca}^{2+}$ binding selectivity filter, and indicates that Orail is indeed a pore forming subunit of the CRAC channel. Prakriya et al. (101) also investigated a glutamate residue at position 190. Mutation of this glutamate to aspartate or even alanine had no effect on channel function; however, the rather extreme alteration to a positively charged glutamine (E190Q) resulted in diminished $\mathrm{Ca}^{2+}$ selectivity. Since subtle effects on channel function were seen with only rather drastic changes in the nature of this amino acid, it may be that this mutation alters the secondary or tertiary structure of the channel, rather than functioning as part of the $\mathrm{Ca}^{2+}$ binding site in the channel pore.

In addition to Orail, mammalian cells have genes for two additional homologs, Orai2 and Orai3. Unlike the case for Stim2, Orai2 appears to function similarly to Orai1, at least when expressed with Stim1 in HEK293 cells (83). Orai2 currents are some- what smaller, however, and it is not yet known if this is an intrinsic property of Orai2 channels, or indicates a lower level of expression in the overexpression studies. Orai3 currents are even smaller, such that $\mathrm{Ca}^{2+}$ currents from co-expression of Stim1 and Orai3 in HEK293 cells are below the limits of detection. However, Orai3-dependent currents can be observed when $\mathrm{Na}^{+}$carries the current (unpublished observation), and Orai3 can rescue store-operated entry following knockdown of Orai1 in HEK293 cells (83). Whether Orai2 and 3 form distinct store-operated channels in specific cell types, or function as subunits of heteromeric channels with Orai1 will be a topic of future investigation.

\section{Communication between Stim1 and Orai1}

The evidence is very strong that the signaling pathway for capacitative calcium entry begins with the $\mathrm{Ca}^{2+}$ sensor, Stim1, and culminates in the activation of channels composed partly or wholly of Orai subunits. The obvious question is how does Stim1 convey information of depleted $\mathrm{Ca}^{2+}$ stores to Orai channels? The simplest answer is that when Stim1 coalesces into punctae and approaches the plasma membrane, it directly interacts with Orai channels there. In support of this idea, Yeromin et al. (102) reported that Drosophila Stim and Orai could be co- $^{-}$ immunoprecipitated, and this association was increased by depletion of $\mathrm{Ca}^{2+}$ stores. However, Feske et al. (95) failed to observe any co-immumoprecipitation of mammalian Stim1 and Orai1. Vig et al. (103) reported $\mathrm{co}^{-}$immunoprecipitation of transfected and tagged Stim1 and Orail, but did not assess effects of store depletion. Nonetheless, it is clear from the work of Luik et al. (104) that communication between Stim1 and Orail occurs over very short distances; these investigators observed that Orai1 was recruited to sites of Stim1 punctae formation, and that $\mathrm{Ca}^{2+}$ entry was spatially restricted to these plasma membrane sites as well. Finally, although a direct interaction between Stim1 and Orai seems the simplest mechanism for signaling from intracellular stores to the plasma membrane channels, there is nothing to rule out the generation of a secondary 
message downstream of Stim1 that acts on Orai, for example, the CIF and iPLA 2 pathway described previously (39).

\section{Conclusions}

In just the past two years, the discovery of Stim and Orai proteins has revolutionized our thinking about capacitative calcium entry and $I_{\text {crac }}$. It is remarkable how quickly different laboratories confirmed the dependence of $I_{\text {crac }}$ on these two genes, and confirmed the ability of these two proteins to recapitulate the long-known properties of CRAC channels. In fact, it could be said that these are the only aspects of the $I_{\text {crac }}$ story upon which all (or most) seem to agree. The current ideas about Stim1 and Orai action are consistent with a number of earlier ideas about store-operated entry; for example, the presence of a small, specialized component of the endoplasmic reticulum dedicated to communicating with plasma membrane channels; the observation that biophysical properties of CRAC channels differ substantially from conventional ion channels, predicting that they may also differ substantially in their structure ; the general finding that $\mathrm{Ca}^{2+}$ refills the stores efficiently without resulting in a rise in global cytoplasmic $\mathrm{Ca}^{2+}$ and the suggested close physical association between sites of endoplasmic reticulum signaling and plasma membrane $\mathrm{Ca}^{2+}$ entry. One could argue that the original idea of Irvine (57) - conformational coupling - is at least partially vindicated by the current model. However, it appears to be Stim1 rather than $\mathrm{IP}_{3}$ receptors that are responsible for this coupling. A summary of the store-operated pathway incorporating the functions of Stim1 and Orais is shown in Fig. 5. At present there are some general questions that will no doubt be attacked and hopefully resolved in the not too distant future: (i) Are any other players or proteins necessary for activation of capacitative calcium entry and/or $I_{\text {crac} \text { ? (ii) }}$ What is the role, if any, of plasma membrane Stim1? (iii) What is the composition of native CRAC channels (Orai homo- or heteromultimers ; or combinations with TRPs)? (iv) Are there mechanisms of store -operated entry involving other modes of activation

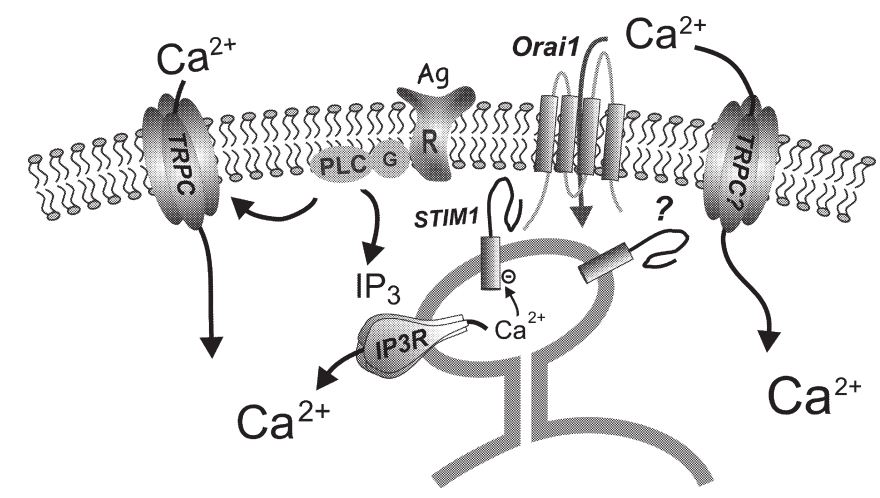

Fig. 5. Current model for the roles of Stim1 and Orais. Agonist activation of a plasma membrane receptor (R) results in formation of $\mathrm{IP}_{3}$, which activates the $\mathrm{IP}_{3}$ receptor (IP3R) causing discharge of store $\mathrm{Ca}^{2+}$ from a subcompartment of the endoplasmic reticulum. Within this subcompartment, $\mathrm{Ca}^{2+}$ binds reversibly to an EF hand motif in Stim1; depletion of $\mathrm{Ca}^{2+}$ results in Stim1 without $\mathrm{Ca}^{2+}$ bound, which causes Stim1 to redistribute within the endoplasmic reticulum to areas near Orai within the plasma membrane. Stiml then activates $\mathrm{Ca}^{2+}$ -selective Orai channels; the mechanism whereby this activation is accomplished is unknown. Stiml is also present in the plasma membrane (not shown), although its function there is unclear. TRPC channels can be activated by phospholipase C -derived signals; there is some evidence that they can be store -regulated in a Stim1-dependent manner.

(other than Stim1) and other store-operated channels (other than Orais)? (v) How do these molecules function in specialized cells and tissues; for example, despite the fact that the capacitative calcium entry story was born of experimental work in salivary glands, the functions of these new molecules and mechanisms in salivary glands have not yet been investigated (or at least, as yet, reported). Nonetheless, the availability of Stim1 and Orai cDNAs will lead to a detailed structural understanding of the various modes of regulation and activation of this pathway. Such information may ultimately prove of use in designing novel pharmacological reagents to aid in the treatment of a number of diseases in which the store-operated entry pathway is thought to play a role.

\section{References}

1. Dodds MW, Johnson DA, Mobley CC and Hattaway KM : Parotid saliva protein profiles in caries-free and caries-active adults. Oral Surg Oral Med Oral Pathol Oral Radiol Endod, 83 : 244-251, 1997. 
2. Yeh CK, Johnson DA and Dodds MW : Impact of aging on human salivary gland function : a community-based study. Aging (Milano), 10 : 421-428, 1998.

3. Chambers MS: Sjogren's syndrome. ORL Head Neck Nurs, 22 : 22-30, 2004.

4. Dodds MW, Johnson DA and Yeh CK : Health benefits of saliva: a review. J Dent, 33 : 223-233, 2005.

5. Llena-Puy C: The role of saliva in maintaining oral health and as an aid to diagnosis. Med Oral Patol Oral Cir Bucal, 11: E449-E455, 2006.

6. Putney JW, Jr.: Identification of cellular activation mechanisms associated with salivary secretion. Ann Rev Physiol, 48: 75-88, 1986.

7. Melvin JE, Yule D, Shuttleworth T and Begenisich T: REGULATION OF FLUID AND ELECTROLYTE SECRETION IN SALIVARY GLAND ACINAR CELLS. Annual Review of Physiology, 67 : 445-469, 2005.

8. Belan P, Gardner J, Gerasimenko O, Gerasimenko J, Mills CL, Petersen $\mathrm{OH}$ and Tepikin AV : Isoproterenol evokes extracellular $\mathrm{Ca}^{2+}$ spikes due to secretory events in salivary gland cells. J Biol Chem, 273 : 4106-4111, 1998.

9. Schramm M and Selinger $Z$ : The functions of cyclic AMP and calcium as alternative second messengers in parotid gland and pancreas. J Cyclic Nucleotide Res, 1: 181-192, 1975.

10. Turner RJ and Sugiya $H$ : Understanding salivary fluid and protein secretion. Oral Dis, 8: 3-11, 2002.

11. Fujita-Yoshigaki J, Dohke Y, Hara-Yokoyama M, Furuyama S and Sugiya H : Snare proteins essential for cyclic AMP-regulated exocytosis in salivary glands. Eur J Morphol, 36 Suppl : 46-49, 1998.

12. Sugiya $\mathrm{H}$ and Furuyama $\mathrm{S}$ : The activation of inositol-mobilizing receptors in salivary gland. Biomed Res, 10 : 111-121, 1989.

13. Berridge MJ : Inositol trisphosphate and diacylglycerol: Two interacting second messengers. Ann Rev Biochem, 56 : 159-193, 1987.

14. Putney JW, Jr., McKinney JS, Aub DL and Leslie BA : Phorbol ester-induced protein secretion in rat parotid gland. Relationship to the role of inositol lipid breakdown and protein kinase $\mathrm{C}$ activation in stimulus-secretion coupling. Mol Pharmacol, 26 : 261-266, 1984.

15. Putney JW, Jr.: Biphasic modulation of potassium release in rat parotid gland by carbachol and phenylephrine. J Pharmacol Exp Ther, 198: 375-384, 1976.

16. Putney JW, Jr.: Muscarinic, alpha-adrenergic and peptide receptors regulate the same calcium influx sites in the parotid gland. J Physiol (Lond), 268: 139 $-149,1977$.

17. Menniti FS, Bird GStJ, Takemura H, Thastrup O, Potter BVL and Putney JW, Jr.: Mobilization of calcium by inositol trisphosphate from permeabilized rat parotid acinar cells. Evidence for translocation of calcium from uptake to release sites within the inositol 1,4,5-trisphosphate- ${ }^{-}$and thapsigargin-sensitive calcium pool. J Biol Chem, 266: 13646-13653, 1991.

18. Mikoshiba K: Inositol 1,4,5-trisphosphate receptor. Trends Pharmacol Sci, 14: 86-89, 1993.

19. Berridge MJ and Galione A : Cytosolic calcium oscillators. FASEB J, 2: 3074-3082, 1988.

20. Thomas AP, Renard DC and Rooney TA: Spatial organization of $\mathrm{Ca}^{2+}$ signalling and $\operatorname{Ins}(1,4,5) \mathrm{P} 3$ action. Adv Second Messenger Phosphoprotein Res, 26: 225-263, 1992.

21. Thomas AP, Bird GStJ, Hajnóczky G, Robb-Gaspers LD and Putney JW, Jr.: Spatial and temporal aspects of cellular calcium signalling. FASEB J, 10 : 1505-1517, 1996.

22. Gray PTA : Oscillations of free cytosolic calcium evoked by cholinergic and catecholaminergic agonists in rat parotid acinar cells. J Physiol (Lond), 406: 35-53, 1988.

23. Bird GS, Rossier MF, Obie JF and Putney JW, Jr. : Sinusoidal oscillations in intracellular calcium requiring negative feedback by protein kinase C. J Biol Chem, 268: 8425-8428, 1993.

24. Putney JW, Jr.: A model for receptor-regulated calcium entry. Cell Calcium, 7: 1-12, 1986.

25. Takemura H and Putney JW, Jr. : Capacitative calcium entry in parotid acinar cells. Biochem J, 258 : 409-412, 1989.

26. Takemura H, Hughes AR, Thastrup O and Putney JW, Jr.: Activation of calcium entry by the tumor promoter, thapsigargin, in parotid acinar cells. Evidence that an intracellular calcium pool, and not an inositol phosphate, regulates calcium fluxes at the plasma membrane. J Biol Chem, 264: 12266-12271, 1989.

27. Parod RJ and Putney JW, Jr. : The role of calcium in the receptor mediated control of potassium permeability in the rat lacrimal gland. J Physiol (Lond), 281 : 371-381, 1978.

28. Hoth $\mathrm{M}$ and Penner $\mathrm{R}$ : Depletion of intracellular calcium stores activates a calcium current in mast cells. Nature, 355 : 353-355, 1992.

29. Putney JW, Jr.: Capacitative calcium entry revisited. Cell Calcium, 11: 611-624, 1990.

30. Hoth $\mathrm{M}$ and Penner $\mathrm{R}$ : Calcium release-activated calcium current in rat mast cells. J Physiol (Lond), 465: 359-386, 1993.

31. Zweifach A and Lewis RS: Mitogen-regulated $\mathrm{Ca}^{2+}$ current of $\mathrm{T}$ lymphocytes is activated by depletion of intracellular $\mathrm{Ca}^{2+}$ stores. Proc Nat Acad Sci USA, 90 : 6295-6299, 1993. 
32. Zweifach A and Lewis RS : Slow calcium-dependent inactivation of depletion-activated calcium current. J Biol Chem, 270 : 14445-14451, 1995.

33. Zweifach A and Lewis RS: Calcium-dependent potentiation of store-operated calcium channels in T lymphocytes. J Gen Physiol, 107 : 597-610, 1996.

34. Putney JW, Jr. and Bird GStJ: The signal for capacitative calcium entry. Cell, 75: 199-201, 1993.

35. Berridge MJ : Capacitative calcium entry. Biochem J, 312 : 1-11, 1995.

36. Putney JW, Jr. Capacitative Calcium Entry. Austin, TX: Landes Biomedical Publishing, 1997.

37. Parekh AB and Penner R: Store depletion and calcium influx. Physiol Rev, 77 : 901-930, 1997.

38. Putney JW, Jr. and McKay RR: Capacitative calcium entry channels. Bioessays, 21: 38-46, 1999.

39. Bolotina VM and Csutora P: CIF and other mysteries of the store-operated $\mathrm{Ca}^{2+}$-entry pathway. Trends Biochem Sci, 30: 378-387, 2005.

40. Parekh $\mathrm{AB}$ and Putney JW, Jr.: Store-operated calcium channels. Physiol Rev, 85 : 757-810, 2005.

41. Somasundaram B, Norman JC and Mahaut-Smith MP : Primaquine, an inhibitor of vesicular transport, blocks the calcium release activated current in rat megakaryocytes. Biochem J, 309: 725-729, 1995.

42. Pandol SJ and Schoeffield-Payne MS : Cyclic GMP mediates the agonist-stimulated increase in plasma membrane calcium entry in the pancreatic acinar cell. J Biol Chem, 265 : 12846-12853, 1990.

43. Xu X, Star RA, Tortorici G and Muallem S: Depletion of intracellular $\mathrm{Ca}^{2+}$ stores activates nitricoxide synthase to generate cGMP and regulate $\mathrm{Ca}^{2+}$ influx. J Biol Chem, 269 : 12645-12653, 1994.

44. Graier WF, Simecek S and Sturek M: Cytochrome $\mathrm{P} 450$ mono-oxygenase-regulated signalling of $\mathrm{Ca}^{2+}$ entry in human and bovine endothelial cells. J Physiol (Lond), 482 : 259-274, 1995.

45. Gailly $\mathrm{P}: \mathrm{Ca}^{2+}$ entry in $\mathrm{CHO}$ cells, after $\mathrm{Ca}^{2+}$ stores depletion, is mediated by arachidonic acid. Cell Calcium, 24 : 293-304, 1998.

46. Rzigalinski BA, Willoughby KA, Hoffman SW, Falck JR and Ellis EF : Calcium influx factor, further evidence it is 5,6-epoxyeicosatrienoic acid. J Biol Chem, 274: 175-185, 1999.

47. Thompson SH: Cyclic GMP-gated channels in a sympathetic neuron cell line. J Gen Physiol, 110 : 155 -164, 1997.

48. Mignen O, Thompson JL, Yule DI and Shuttleworth TJ : Agonist activation of arachidonate-regulated $\mathrm{Ca}^{2+}$-selective (ARC) channels in murine parotid and pancreatic acinar cells. J Physiol, 564: 791-801, 2005.

49. Randriamampita $\mathrm{C}$ and Tsien RY: Emptying of intracellular $\mathrm{Ca}^{2+}$ stores releases a novel small messenger that stimulates $\mathrm{Ca}^{2+}$ influx. Nature, $364: 809$
$-814,1993$

50. Thomas D and Hanley MR: Evaluation of calcium influx factors from stimulated Jurkat Tlymphocytes by microinjection into Xenopus oocytes. J Biol Chem, 270 : 6429-6432, 1995.

51. Kim HY, Thomas D and Hanley MR : Chromatographic resolution of an intracellular calcium influx factor from thapsigargin-activated Jurkat cells. J Biol Chem, 270 : 9706-9708, 1995.

52. Thomas D, Kim HY and Hanley MR: Regulation of inositol trisphosphate-induced membrane currents in Xenopus oocytes by a Jurkat cell calcium influx factor. Biochem J, 318 : 649-656, 1996.

53. Csutora P, Su Z, Kim HY, Bugrim A, Cunningham KW, Nuccitelli R, Keizer JE, Hanley MR, Blalock JE and Marchase RB : Calcium influx factor is synthesized by yeast and mammalian cells depleted of organellar calcium stores. Proc Nat Acad Sci USA, 96 : 121-126, 1999.

54. Trepakova ES, Csutora P, Hunton DL, Marchase $\mathrm{RB}$, Cohen RA and Bolotina VM : Calcium influx factor (CIF) directly activates store-operated cation channels in vascular smooth muscle cells. J Biol Chem, 275 : 26158-26163, 2000.

55. Smani T, Zakharov SI, Leno E, Csutora P, Trepakova ES and Bolotina VM: $\mathrm{Ca}^{2+}$-independent phospholipase A2 is a novel determinant of store- operated $\mathrm{Ca}^{2+}$ entry. J Biol Chem, 278: 11909-11915, 2003.

56. Csutora P, Zarayskiy V, Peter K, Monje F, Smani T, Zakharov SI, Litvinov D and Bolotina VM: Activation Mechanism for CRAC Current and Store-operated $\mathrm{Ca}^{2+}$ Entry : CALCIUM INFLUX FACTOR AND $\mathrm{Ca}^{2+}$-INDEPENDENT PHOSPHOLIPASE A2betaMEDIATED PATHWAY. J Biol Chem, 281 : 3492634935, 2006.

57. Irvine RF : "Quantal" $\mathrm{Ca}^{2+}$ release and the control of $\mathrm{Ca}^{2+}$ entry by inositol phosphates - a possible mechanism. FEBS Letters, 263 : 5-9, 1990.

58. Jaconi M, Pyle J, Bortolon R, Ou J and Clapham D : Calcium release and influx colocalize to the endoplasmic reticulum. Current Biol, 7 : 599-602, 1997.

59. Patterson RL, van Rossum DB and Gill DL: Storeoperated $\mathrm{Ca}^{2+}$ entry: evidence for a secretion-like coupling model. Cell, 98: 487-499, 1999.

60. Bakowski D, Glitsch MD and Parekh AB : An examination of the secretion-like coupling model for the activation of the $\mathrm{Ca}^{2+}$ release-activated $\mathrm{Ca}^{2+}$ current $I_{\text {crac }}$ in RBL-1 cells. J Physiol (Lond), 532: 55-71, 2001.

61. Hardie RC and Minke B: Novel $\mathrm{Ca}^{2+}$ channels underlying transduction in Drosophila photoreceptors: implications for phosphoinositide-mediated $\mathrm{Ca}^{2+}$ mobilization. Trends Neurosci, 16:371-376, 1993. 
62. Hardie RC and Minke B: The trp gene is essential for a light-activated $\mathrm{Ca}^{2+}$ channel in drosophila photoreceptors. Neuron, 8: 643-651, 1992.

63. Zhu X, Jiang M, Peyton M, Boulay G, Hurst R, Stefani E and Birnbaumer L: trp, a novel mammalian gene family essential for agonist-activated capacitative $\mathrm{Ca}^{2+}$ entry. Cell, 85: 661-671, 1996.

64. Zitt C, Zobel A, Obukhov AG, Harteneck C, Kalkbrenner F, Lückhoff A and Schultz G: Cloning and functional expression of a human $\mathrm{Ca}^{2+}$-permeable cation channel activated by calcium store depletion. Neuron, 16: 1189-1196, 1996.

65. Kiselyov K, Xu X, Mozhayeva G, Kuo T, Pessah I, Mignery G, Zhu X, Birnbaumer L and Muallem S: Functional interaction between $\operatorname{InsP}_{3}$ receptors and store-operated Htrp3 channels. Nature, 396: 478482, 1998.

66. Zhu X, Jiang $\mathrm{M}$ and Birnbaumer L: Receptoractivated $\mathrm{Ca}^{2+}$ influx via human Trp3 stably expressed in human embryonic kidney (HEK)293 cells. Evidence for a non-capacitative calcium entry. J Biol Chem, 273 : 133-142, 1998.

67. Trebak M, Bird GStJ, McKay RR, Birnbaumer L and Putney JW, Jr.: Signaling mechanism for receptoractivated TRPC3 channels. J Biol Chem, 278 : 1624416252, 2003.

68. Mori Y, Wakamori M, Miyakawa T, Hermosura M, Hara Y, Nishida M, Hirose K, Mizushima A, Kurosaki M, Mori E, Gotoh K, Okada T, Fleig A, Penner R, Iino $\mathrm{M}$ and Kurosaki $\mathrm{T}$ : Transient receptor potential 1 regulates capacitative $\mathrm{Ca}^{2+}$ entry and $\mathrm{Ca}^{2+}$ release from endoplasmic reticulum in $\mathrm{B}$ lymphocytes. J Exp Med, 195 : 673-681, 2002.

69. Vazquez G, Lièvremont J-P, Bird GStJ and Putney JW, Jr. : Human Trp3 forms both inositol trisphosphate receptor-dependent and receptor-independent store-operated cation channels in DT40 avian Blymphocytes. Proc Nat Acad Sci USA, 98: 1177711782, 2001.

70. Vazquez G, Wedel BJ, Trebak M, Bird GStJ and Putney JW, Jr. : Expression level of TRPC3 channel determines its mechanism of activation. J Biol Chem, 278 : 21649-21654, 2003.

71. Lievremont JP, Bird GS and Putney JW, Jr. : Canonical transient receptor potential TRPC7 can function as both a receptor- and store-operated channel in HEK-293 cells. Am J Physiol Cell Physiol, 287: C1709-C1716, 2004.

72. Zeng F, Xu SZ, Jackson PK, McHugh D, Kumar B, Fountain SJ and Beech DJ : Human TRPC5 channel activated by a multiplicity of signals in a single cell. J Physiol, 559 : 739-750, 2004.

73. Vazquez G, Wedel BJ, Aziz O, Trebak M and Putney JW, Jr.: The mammalian TRPC cation channels.
Biochim Biophys Acta, 1742: 21-36, 2004.

74. Putney JW, Jr.: Physiological mechanisms of TRPC activation. Pflugers Arch, 451: 29-34, 2005.

75. Dietrich A, Schnitzler M, Kalwa H, Storch U and Gudermann T: Functional characterization and physiological relevance of the TRPC3/6/7 subfamily of cation channels. Naunyn Schmiedebergs Arch Pharmacol, 371 : 257-265, 2005.

76. Groschner K and Rosker C: TRPC3: a versatile transducer molecule that serves integration and diversification of cellular signals. Naunyn Schmiedebergs Arch Pharmacol, 371: 251-256, 2005.

77. Freichel M, Vennekens R, Olausson J, Stolz S, Philipp SE, Weissgerber P and Flockerzi V : Functional role of TRPC proteins in native systems: implications from knockout and knock-down studies. J Physiol, 567 : 59-66, 2005.

78. Roos J, DiGregorio PJ, Yeromin AV, Ohlsen K, Lioudyno M, Zhang S, Safrina O, Kozak JA, Wagner SL, Cahalan MD, Velicelebi G and Stauderman KA : STIM1, an essential and conserved component of store-operated $\mathrm{Ca}^{2+}$ channel function. J Cell Biol, 169: 435-445, 2005.

79. Liou J, Kim ML, Heo WD, Jones JT, Myers JW, Ferrell JE, Jr. and Meyer T : STIM is a $\mathrm{Ca}^{2+}$ sensor essential for $\mathrm{Ca}^{2+}$-store-depletion-triggered $\mathrm{Ca}^{2+}$ influx. Curr Biol, 15 : 1235-1241, 2005.

80. Soboloff J, Spassova MA, Hewavitharana T, He LP, $\mathrm{Xu}$ W, Johnstone LS, Dziadek MA and Gill DL: STIM2 is an inhibitor of STIM1-mediated storeoperated $\mathrm{Ca}^{2+}$ Entry. Curr Biol, 16: 1465-1470, 2006.

81. Zhang SL, Yu Y, Roos J, Kozak JA, Deerinck TJ, Ellisman MH, Stauderman KA and Cahalan MD: STIM1 is a $\mathrm{Ca}^{2+}$ sensor that activates CRAC channels and migrates from the $\mathrm{Ca}^{2+}$ store to the plasma membrane. Nature, 437 : 902-905, 2005.

82. Spassova M, Soboloff J, He L-P, Xu W, Dziadek M and Gill DL: STIM1 has a plasma membrane role in the activation of store- operated $\mathrm{Ca}^{2+}$ channels. Proc Nat Acad Sci USA, 103 : 4040-4045, 2006.

83. Mercer JC, DeHaven WI, Smyth JT, Wedel B, Boyles RR, Bird GS and Putney JW, Jr. : Large store-operated calcium- ${ }^{-}$selected currents due to $\mathrm{co}^{-}$expression of orai1 or orai2 with the intracellular calcium sensor, stim1. J Biol Chem, 281 : 24979-24990, 2006.

84. Ribeiro CMP, McKay RR, Hosoki E, Bird GS and Putney JW, Jr.: Effects of elevated cytoplasmic calcium and protein kinase $\mathrm{C}$ on endoplasmic reticulum structure and function in HEK293 cells. Cell Calcium, 27 : 175-185, 2000.

85. Ribeiro CMP and Putney JW, Jr.: Differential effects of protein kinase $\mathrm{C}$ activation on calcium storage and capacitative calcium entry in NIH 3T3 cells. J Biol Chem, 271 : 21522-21528, 1996. 
86. Parekh AB, Fleig A and Penner R: The store-operated calcium current $I_{\text {crac }}$ : nonlinear activation by $\mathrm{InsP}_{3}$ and dissociation from calcium release. Cell, 89 : 973-980, 1997.

87. Huang Y and Putney JW, Jr. : Relationship between intracellular calcium store depletion and calcium release-activated calcium current $\left(I_{\text {crac }}\right)$ in a mast cell line (RBL-1). J Biol Chem, 273 : 19554-19559, 1998.

88. Broad LM, Armstrong DL and Putney JW, Jr.: Role of the $\mathrm{IP}_{3}$ receptor in $\mathrm{Ca}^{2+}$ feedback inhibition of calcium release-activated calcium current $\left(I_{\text {crac }}\right)$. J Biol Chem, 274: 32881-32888, 1999.

89. Turner H, Fleig A, Stokes A, Kinet JP and Penner R : Discrimination of intracellular calcium store subcompartments using TRPV1 (transient receptor potential channel, vanilloid subfamily member 1) release channel activity. Biochem J, 371: 341-350, 2003.

90. Wisnoskey BJ, Sinkins WG and Schilling WP : Activation of vanilloid receptor type I in the endoplasmic reticulum fails to activate store-operated $\mathrm{Ca}^{2+}$ entry. Biochem J, 372 : 517-528, 2003.

91. Baba Y, Hayashi K, Fujii Y, Mizushima A, Watarai H, Wakamori M, Numaga T, Mori Y, Iino M, Hikida $\mathrm{M}$ and Kurosaki T: Coupling of STIM1 to storeoperated $\mathrm{Ca}^{2+}$ entry through its constitutive and inducible movement in the endoplasmic reticulum. Proc Nat Acad Sci USA, 103 : 16704-16709, 2006.

92. Oritani $\mathrm{K}$ and Kincade $\mathrm{PW}$ : Identification of stromal cell products that interact with pre-B cells. J Cell Biol, 134: 771-782, 1996.

93. Manji SS, Parker NJ, Williams RT, Van SL, Pearson RB, Dziadek M and Smith PJ : STIM1: a novel phosphoprotein located at the cell surface. Biochim Biophys Acta, 1481: 147-155, 2000.

94. Williams RT, Senior PV, Van SL, Layton JE, Smith PJ and Dziadek MA : Stromal interaction molecule 1 (STIM1), a transmembrane protein with growth suppressor activity, contains an extracellular SAM domain modified by $\mathrm{N}$-linked glycosylation. Biochim Biophys Acta, 1596 : 131-137, 2002.

95. Feske S, Gwack Y, Prakriya M, Srikanth S, Puppel SH, Tanasa B, Hogan PG, Lewis RS, Daly M and Rao A : A mutation in Orail causes immune deficiency by abrogating CRAC channel function.
Nature, 441: 179-185, 2006.

96. Vig M, Peinelt C, Beck A, Koomoa DL, Rabah D, Koblan-Huberson M, Kraft S, Turner H, Fleig A, Penner $\mathrm{R}$ and Kinet JP: CRACM1 Is a Plasma Membrane Protein Essential for Store-Operated $\mathrm{Ca}^{2+}$ Entry. Science, 312: 1220-1223, 2006.

97. Zhang SL, Yeromin AV, Zhang XH, Yu Y, Safrina O, Penna A, Roos J, Stauderman KA and Cahalan MD: Genome-wide RNAi screen of $\mathrm{Ca}^{2+}$ influx identifies genes that regulate $\mathrm{Ca}^{2+}$ release-activated $\mathrm{Ca}^{2+}$ channel activity. Proc Natl Acad Sci USA, 103 : 93579362, 2006.

98. Peinelt C, Vig M, Koomoa DL, Beck A, Nadler MJS, Koblan-Huberson M, Lis A, Fleig A, Penner R and Kinet JP : Amplification of CRAC current by STIM1 and CRACM1 (Orai1). Nat Cell Biol, 8: 771-773, 2006.

99. Soboloff J, Spassova MA, Tang XD, Hewavitharana T, Xu W and Gill DL: Orail and STIM Reconstitute Store-operated Calcium Channel Function. J Biol Chem, 281 : 20661-20665, 2006.

100. Trebak M, Bird GStJ, McKay RR and Putney JW, Jr. : Comparison of human TRPC3 channels in receptor-activated and store-operated modes. Differential sensitivity to channel blockers suggests fundamental differences in channel composition. J Biol Chem, 277 : 21617-21623, 2002.

101. Prakriya M, Feske S, Gwack Y, Srikanth S, Rao A and Hogan PG: Orail is an essential pore subunit of the CRAC channel. Nature, 443 : 230-233, 2006.

102. Yeromin AV, Zhang SL, Jiang W, Yu Y, Safrina O and Cahalan MD: Molecular identification of the CRAC channel by altered ion selectivity in a mutant of Orai. Nature, 443: 226-229, 2006.

103. Vig M, Beck A, Billingsley JM, Lis A, Parvez S, Peinelt C, Koomoa DL, Soboloff J, Gill DL and Fleig A : CRACM1 Multimers Form the Ion-Selective Pore of the CRAC Channel. Current Biol, 16: 20732079, 2006.

104. Luik RM, Wu MM, Buchanan J and Lewis RS: The elementary unit of store-operated $\mathrm{Ca}^{2+}$ entry : local activation of CRAC channels by STIM1 at ERplasma membrane junctions. J Cell Biol, 174: 815825, 2006. 